\title{
Article 282 and Centrally Sponsored Schemes: Implications on Fiscal Federalism in India
}

\author{
Richa Dwivedi, Abhinav Shrivastava \\ Assistant Professor, \\ Symbiosis Law School, Pune \\ Symbiosis International (Deemed University), Pune \\ Email Id: richa.dwivedi92@gmail.com
}

\begin{abstract}
India is a quasi-federal country which implies that on one hand when the States require autonomy and flexibility in working, on other hand it also required an interdependence between the Centre and the state, thereby giving birth to the idea of cooperative federalism. The constitution of India has clearly given a framework demarcating the power, functions and responsibilities of each level of government and there are a few provisions which aim at cooperative federalism. Article 282 of the Indian Constitution is one such provision which empowers both the Centre as well as the State to provide grants for public purpose.
\end{abstract}

The paper seeks to examine the issues and challenges faced by the fiscal federalism in India. The paper also delves into the constitutional provision to understand and identify the use of Article 282. The current debate with respect to the state autonomy in matters of finances and prioritizing the need of the states compel the analysis of Article 282 with reference to the Centrally Sponsored Schemes (CSS). The paper thus aims to give a comprehensive analysis of Article 282 and its use and implications on fiscal federalism in India.

Keywords: Fiscal Federalism, Article 282, Centrally Sponsored Schemes (CSS), State autonomy, Public purpose 


\section{Introduction}

India is a Quasi federal country which means the powers, functions and responsibilities have been divided between the two levels of the government. The federal structure is rooted in the constitutional scheme wherein the legislative, executive and the financial powers are divided amongst the two levels of government. Fiscal Federalism is one of the strongest pillar of any democracy as all the welfare measures need to be supported by the finances. Increasing significance to the welfare of the people has been attached by our Constitution as well as the international community. Therefore, this necessitates the study of fiscal federalism with respect to social welfare of the people.

Indian fiscal federalism has been debated a lot due to the challenges that it aims to unravel. The major challenges for fiscal federalism are to balance the vertical and fiscal federalism. In order to unravel the same, the constitution has provided with an institution called the Finance Commission. ${ }^{1}$ The constitution has also clearly demarcated the power of revenue collection that vests with the Union as well as the States and that the revenues need to be shared amongst the two. ${ }^{2}$ However, the constitution did not provide the principle of distribution of revenues and has left it to the recommendation of finance commission. The Constitution has however prescribed the methods of devolution through various provisions like Article $270^{3}, 275^{4}$ and $282^{5}$. These devolutions were made through various institutions throughout these years like the Finance Commission, the Planning Commission and the central ministries.

\footnotetext{
1 280. Finance Commission. "(1) The President shall, within two years from the commencement of this Constitution and thereafter at the expiration of every fifth year or at such earlier time as the President considers necessary, by order constitute a Finance Commission which shall consist of a Chairman and four other members to be appointed by the President."

${ }^{2}$ 270(1). Taxes levied and distributed between the Union and the States. "All taxes and duties referred to in the Union List, except the duties and taxes referred to in articles 2 [268, 269 and 269A], respectively, surcharge on taxes and duties referred to in article 271 and any cess levied for specific purposes under any law made by Parliament shall be levied and collected by the Government of India and shall be distributed between the Union and the States in the manner provided in clause (2)."

${ }^{3}$ ibid

${ }^{4} 275(1)$. Grants from the Union to certain States. "Such sums as Parliament may by law provide shall be charged on the Consolidated Fund of India in each year as grants-in-aid of the revenues of such States as Parliament may determine to be in need of assistance, and different sums may be fixed for different States"

${ }^{5}$ 282. Expenditure defrayable by the Union or a State out of its revenues. "The Union or a State may make any grants for any public purpose, notwithstanding that the purpose is not one with respect to which Parliament or the Legislature of the State, as the case may be, may make laws."
} 
The finance commission provides for the distribution of revenue which is based on various factors and it changes as per the requirements of the society every five years. The grants in aid under article 275 is also decided by the Finance Commission. The finance commission decided the principle and the quantum of grants to be provided to the states. The principle on which grants are given have also been subjected to criticism in the present times. This devolution of money has been done so that the states can spend it in economic as well as social activities in the states. Various literature suggests that the main issue with respect to devolution of funds is the devolution that falls outside the purview of the Finance Commission. This intergovernmental fiscal transfer (IGFT) outside the purview of the FCs is the most sensitive part of the federal-state fiscal relations in India, as the states feel that these transfers are large, discretionary, arbitrary, and regressive. ${ }^{6}$

The constitution also provides for Grants under Article 282 of the Indian Constitution which has been under considerable discussion and controversy in the recent past for circumscribing the state autonomy and undermining the spirit of federalism. Article 282 which talks about grants from the Union and States for public purpose and thus has been the provision to grants funds for the Centrally Sponsored Schemes (CSS). ${ }^{7}$ Along with Article 282, the centrally sponsored schemes have also been subject to debate and controversy.

Article 282 suggests implementation of the idea of cooperative federalism, however, its use questions the purpose with which it has been incorporated and subjects the provision under scrutiny. The paper will analyze Article 282 and the centrally sponsored schemes. Further the paper will highlight the challenges that the present use of Article 282 and CSS are posing to the fiscal federalism in India. The paper aims to suggest a framework to establish cooperative federalism in India.

\section{Analysis of Article 282}

Article 282 of the Indian Constitution is a provision which enables the Union as well as the State government to make grants for any public purpose. The provision further states that the funding can be made for any subject matter irrespective of the fact if it falls within the ambit

\footnotetext{
${ }^{6}$ Reddy, Y. V., and G. R. Reddy. 2019. Indian Fiscal Federalism. Oxford, UK: Oxford University Press

${ }^{7}$ Kumar Anupama, Centrally Sponsored Schemes and Centre-state Relations: A Comment, Dvara Research, 2020
} 
of the Parliament or the State. Before analyzing the provision in the present situation, it is necessary to identify the intention of the constitution makers behind incorporating such provision. The Constituent assembly debates suggests that there was no discussion or debate that took place with respect to the draft provision 262 and it was as it is adopted to be a part of the Indian Constitution. ${ }^{8}$ However, Shri K Santhanam, Chairman of the 2nd Finance Commission on Article 282, he said- "This was not intended to be one of the major provisions for making readjustments between the Union and the States, if that was the idea, then there was no purpose in evolving such a complicated set of relations of shares, assignments and grants.

There is no purpose in having two Articles enabling the Centre to assist the states-one through the Finance Commission and the other by more executive discretion. In the latter case, even parliamentary legislation is not needed. Of course, it will have to be included in the Budget. But, beyond being an item in the Budget, no further sanction need to be taken. Therefore, in my view, this Article was a residuary a reserve Article to enable the Union to deal with unforeseen contingencies. That was how this Article was used both by the British Government and, after transfer of power, before the first year of the First Five Year Plan." Further $N A$ Palkhivala, Constitutional expert, in his opinion given to $9^{\text {th }}$ Finance Commission, opined "Art.282 is not intended to enable the Union to make such grants as fall properly under Art. 275. Art. 282 embodies merely a residuary power which enables the Union or a State to make any grant for any purpose, irrespective of the question whether the purpose is one over which the grantor has legislative power." ${ }^{99}$ However, if we refer to Dr. Ambedkar in States and Minorities, it suggests that this provision shall not be abridged. ${ }^{10}$ This is because during the developmental stages of the country it is necessary that the Centre make certain specific purpose grants in addition to the grants in aid as given through the route of Finance Commission. ${ }^{11}$

\footnotetext{
8 Constituent Assembly Of India Debates (Proceedings), Volume IX, Aug.10, 1949. Available at: https://www.constitutionofindia.net/constitution_assembly_debates/volume/9/1949-08-10\#9.115.78

${ }^{9}$ Speech of Shri N.K. Singh, Chairman, XVFC at the launch of the book 'Indian Fiscal Federalism, Press Information $\quad$ Bureau, $2019 . \quad$ Available at: https://pib.gov.in/PressReleseDetail.aspx?PRID=1569807\#: :text=Note\%20the\%20Article\%20282\%20of,be\%2 C\%20may\%20make\%20laws.\%E2\%80\%9D

10 Dr. Ambedkar, B.R, States and Minorities, 1945. Available at: https://www.constitutionofindia.net/historical_constitutions/states_and_minorities_dr_b_r_ambedkar_1945 $1 \mathrm{st} \% 20$ January\%201945

${ }^{11} \mathrm{~S} .150(2)$ of the Government of India Act, 1935, which read that "the Federation or a Province may make grants for any purpose, notwithstanding that the purpose is not one with respect to which the Federal or the Provincial Legislature, as the case may be, may make laws."
} 
Thus, the use of word "notwithstanding that the purpose is not one with respect to which Parliament or the Legislature of the State, as the case may be, may make laws" gives the Union lot of flexibility with respect to the use of the provision and granting funds for matters under State List. However, the marginal note with the provision considered it to be a miscellaneous provision which means that the constitution makers did not intend to make it a regular mode of providing grants but only in necessary conditions.

Not only the constitutional experts have debated the use and intention behind incorporating but this provision has been gone under the judicial scrutiny as well in the case of Bhim Singh v. Union of India. ${ }^{12}$ To highlight scope of a term 'Public Purpose' Hon'ble Supreme Court referred to the provisions of the Government of India act, 1935, provisions of the Constitutions of the USA and Australia, where the term 'Public Purpose' is being interpreted in liberal approach. Therefore. The court ruled that no restriction can be imposed upon the horizons of Article 282. The ambit of Article 282 is construed to involve wide dimensions and not to restrict it. Moreover, this Article empowers Union and the States to exercise their spending power to matters not limited to the legislative powers conferred upon them ${ }^{13}$. In practice, the Union government has used article 282 as a substantive and a regular clause to provide developmental grants to the States ${ }^{14}$ One such example of the transfers under Article 282 is the Centrally Sponsored Schemes. Therefore, before analyzing the implication of Article 282 on Fiscal Federalism in India, it is imperative to analyze the idea of Centrally Sponsored Schemes.

\section{Analysis of Centrally Sponsored Schemes}

Realizing the gap between the responsibilities vested with the States and revenue collection of the States, taking the national priorities into account and with the objective to promote welfare of the people ${ }^{15}$, national and Cooperative federalism, the planning commission has initiated the Central Assistance Scheme to the States.

\footnotetext{
12 (2010) 5 SCC 538

${ }^{13}$ Bhim Singh v. Union of India, (2010) 5 SCC 538)

${ }^{14}$ B. P. R. Vithal, Role of Articles 275 and 282 in Federal Fiscal Transfers, Economic and Political Weekly, Vol. 32, No. 28 (Jul. 12-18, 1997), pp. 1689-1691

15 "State to secure a social order for the promotion of welfare of the people-

(1) The State shall strive to promote the welfare of the people by securing and protecting as effectively as it may a social order in which justice, social, economic and political, shall inform all the institutions of the national life."
} 
The Central schemes are generally divided into two categories namely, central sponsored schemes and central sector schemes. While the Union government fully funds the central sector schemes, centrally sponsored schemes are jointly funded by the Centre and states. It is generally decided by looking upon a target area, whether a scheme need to be centrally sponsored or fully funded.

Centrally sponsored schemes are launched with a pre-determined pattern of funding in which both the Centre and a state contributes in a fixed ratio. The advantage of such scheme is that financial resources are shared and states get to work under the supervision and expertise of Centre. Central sponsored schemes are further divided into core schemes and core to the core schemes. This classification has been done to prioritize certain area and giving them a status above all. The number of CSS in India has fluctuated over the years because of continuous demand for restructuring the schemes. There have been so many suggestions and debates surrounding implementation and launch of such schemes. B.K Chaturvedi committee suggested to bring down centrally sponsored schemes so that overlapping can be avoided and efficiency can be improved. There were around $92 \mathrm{CSS}$ at the end of the $3^{\text {rd }}$ Five Year Plan which increased to 262 in $1984 .{ }^{16}$ At present, total number of CSS are 28 . These twenty-eight schemes have been further classified into "core of the core", "core" and "optional schemes". While core schemes involve compulsory participation by the states, states can decide whether to participate in optional schemes. ${ }^{17}$

The prime objective of CSS remains to fulfill the constitutional welfare goal in a best possible coordinated manner. In fact, India has achieved so many social objectives by launching CSS in a well-coordinated way. To a large extent objective of cooperative federalism are achieved but still there remains a scope of improvement and improvisation in that domain. With the

\footnotetext{
${ }^{16}$ Arghya Sengupta, et.al, Examination of the Legal Basis for Conditional Transfers to States and Issues Relating to Performance-Based Incentives for States: Report to the Fifteenth Finance Commission, Vidhi Centre for Legal Policy, 2018.Available at: https://fincomindia.nic.in/writereaddata/html en files/fincom15/StudyReports/Examining\%20the\%20legal\%20 basis $\% 20$ for $\% 20$ conditional $\% 20$ transfers $\% 20$ to $\% 20$ States $\% 20$ and $\% 20$ issues $\% 20$ relating $\% 20$ to $\% 20$ performanc e\%20based\%20incentives.pdf

${ }^{17}$ Report of the Sub-Group of Chief Ministers on Rationalisation of Centrally Sponsored Schemes, 2016. Available at:

http://niti.gov.in/writereaddata/files/OM\%20\%20for\%20circulating\%20decision $\% 20$ of $\% 20$ the $\% 20$ Cabi net $\% 20$ on\%20rationalisation\%20of\%20CSS.PDF.
} 
basic understanding of the Centrally Sponsored Schemes, we can now see the implications of Article 282 and the Centrally sponsored schemes together on the Indian fiscal federalism.

\section{Implications on Fiscal Federalism in India}

The major challenge to fiscal federalism in India has always been that it is eroding the State Autonomy by taking away all the financial powers which will ultimately affect the implementation of the schemes. Centrally Sponsored Schemes which have got the backing for budgetary allocation through Article 282 of the Indian Constitution has played a major role with regard to erosion of State's autonomy. Due to the implementation of the Centrally sponsored schemes, the state's power to exercise its executive power of implementing each scheme has been affected to a great extent as the States have been relying on the Centre for the financial assistance. In effect, the States' power under Article 162 is subject to the Union's exercise of its discretionary spending power under Article 282. ${ }^{18}$

Furthermore, the implementation of CSS is also problematic because it creates regional disparity. The implementation of the Schemes is done by the individual states and therefore, there is a substantial variation in the manner how programmes are implemented. Also, the implementation is also dependent on the resources (non financial) like the infrastructure, staff etc. available with the States and that determines the failure or success of the scheme. ${ }^{19}$

Another major issue with respect to centrally sponsored schemes are is that with time, the sharing of revenue ratio is changing. The state's share in implementing the scheme has increased to a considerable level and this funding has to be done by state's own revenue. The state revenue varies throughout the territory of India because of the disparity in income levels of the States. Low income level state will not be in the condition to contribute their share and thereby may lead to failure of CSS. For instance, despite repeated objections by all the Chief Ministers, the Centre has taken a decision to increase the share of the States in the Sarva Shiksha Abhiyan Programme from 25\% steadily to 50\% under the Eleventh Five-year Plan. Many States are frequently unable to provide the matching shares and consequently forego

\footnotetext{
${ }^{18}$ Supra 7

${ }^{19}$ Rajeshwari Deshpande, Louise Tillin, \& K.K. Kailash. States as laboratories: The politics of social welfare policies in India. India Review (2017) 16(1) 85-105
} 
attendant central transfers which are subsequently reallocated to relatively better-off States as additional allocation, worsening horizontal imbalances.

Also, apart from implementation issue of the CSS, it has been observed recently that in order to implement the schemes, the Centre has directly devolved the funds to the implementing agencies (local bodies) surpassing the State government, which again affects the autonomy of the states and the Centre, through CSS is moving towards a centralised system of governance. With the excessive application of Article 282 by the Centre, grants have become primarily purpose-specific or tied with a host of conditionalities imposed by different central ministries, reducing the States and Panchayats to mere agencies of the central ministries. Over the years, it has been seen that the proportion of central transfer to states have reduced and the devolution of conditional funds have increased.

While formulation of Centrally Sponsored Schemes, the states are not consulted and thereby the state priorities or the state specific needs are compromised and the State's are forced to fund the schemes which does not meet the local needs. Also, since the design is not as per the States, it becomes difficult for them to implement the schemes effectively. ${ }^{20}$ Furthermore, the implication of Centrally Sponsored Schemes is not only on the financial or executive power of the States but in some cases, it extends even to the legislative power. One example can be the JNNURM which requires the State to reduce Stamp Duty rates to at most 5 per cent, a rate which can only be prescribed by the Legislative Assembly. This represents the intrusion of the executive into the space of the legislature ${ }^{21}$

These issues have given birth to the idea of restructuring the Centrally Sponsored Schemes. The last major impetus came with the adoption of the recommendations of the 14th Finance Commission, which increased state governments' share in tax devolution by 10 percentage points. The resultant decrease in the fiscal space available with the GoI reiterated the need to significantly decrease and restructure $\mathrm{CSSs}^{22} \mathrm{~A}$ sub-group of chief ministers on the rationalisation of centrally sponsored schemes was constituted as part of NITI Aayog in March, 2015. Through restructuring, a lot of schemes where the budgetary devolution was minimal

\footnotetext{
${ }^{20}$ Pranay Kotasthane, The Shifting Political Economy of Centrally Sponsored Schemes, The Wire, 2016. Available at: https://thewire.in/agriculture/the-shifting-political-economy-of-centrally-sponsored-schemes

${ }^{21}$ Response to Questionnaire from the Commission on Centre -State Relations, Government of India. Available at: https://www.cpim.org/documents/2008-oct-response-to-commission-on-centre-state-relations.pdf

${ }^{22}$ Avani Kapur, Towards Cooperative Social Policy Financing in India, Centre for Policy Research, 2019.
} 
were either removed or merged with other schemes. As per the 2015 report of NITI Aayog, CSS were to be restructured till $31^{\text {st }}$ March 2020 however, the $15^{\text {th }}$ Finance commission has increased the time beyond 2021.

The changes that followed were minimal. While schemes were reordered under 'umbrella' programmes, within each umbrella programme, sub-schemes continued as before. As per the Union Budget 2016-17, even after the creation of 28 umbrella programmes, there were 950 Central Sector and CSS sub-schemes accounting for about $5 \%$ of the GDP and 9\% of the total GoI expenditure. Three years later, in the interim budget for 2019-20, Central Sector Schemes constituted 12\% of GoI expenditure, up from 9\% in 2016-17; CSSs accounted for another $9 \% .{ }^{23}$ More importantly, there was no real change in the design or implementation of the schemes. Meetings for the planning of education and health programmes continued as before, and the notification to allocate $25 \%$ as flexible, discretionary funds was not reflected in many of the scheme planning documents. In addition to the National Health Mission (NHM), the Budget announced a new CSS, the PM Atma Nirbhar Swasth Bharat Yojana. ${ }^{24}$

Apart from Centrally Sponsored schemes where the funds are devolved (Article 282) from Union to States on the matters listed in any of the list. However, Article 282 also talks about the grant of funds for public purpose even if it is a subject matter of State. This can also be done through the mode of centrally sponsored schemes where when the CSS falls within the subject matter of the Union List, then also the states are mandated to give their share.

\section{Conclusion and Suggestions}

The discussion of the implication of Article 282 and Centrally sponsored schemes on Fiscal Federalism in India clearly shows the erosion of autonomy of States and creation of horizontal imbalance or regional disparity. The objective of the Centrally Sponsored Schemes and Article 282 of the Indian Constitution to promote the spirit of cooperative federalism and welfare of the people is not seen to be accomplished rather it has made the federal structure more centralized and also, the welfare provisions do not take into account the needs and requirements of the people. Centrally Sponsored schemes can be thus considered as a tool to take over the

\footnotetext{
${ }^{23}$ Rathin Roy, Changing Fiscal Dynamics, Seminar Magazine 717 (2019)

${ }^{24}$ Bibek Debroy, A review of centrally sponsored schemes, The new Indian Express Newspaper, 2021.
} 
power over the matters of state concern and it is used as a political tool. Also, despite the attempts to rationalize the Centrally Sponsored Schemes, it has had minimum effects on its implementation.

Also, Article 282 of the Constitution needs to be circumscribed and prescribed some conditions which can be invoked for undertaking schemes and measures which can undercut the basic functioning of the transfer mechanism through the Finance Commission. Planning Commission, an extra constitutional body has used or rather say misused the provision Article 282 to fulfil the political motives and thus needs to be circumscribed. Thus, the following recommendations can resolve the problem to some extent:

1. The Restructuring of the Centrally Sponsored Schemes should not only lead to merging the schemes. There must be proper restructuring done in consultation with the States with respect to the design and implementation of the policy.

2. While restructuring the Centrally sponsored schemes, it must be taken into account that the states are asked for their share only if the scheme related to the subject matter of the State and otherwise, all the schemes falling under the subject matter of Union should be brought within the ambit of Centre Sector schemes which will be completely funded by the Centre.

3. Use of Article 282 for the purpose of grants for public purpose must be used only in exceptional cases and contingent situations and not be made a norm.

4. Use of Article 282 to provide budgetary allowance to Centrally Sponsored Schemes must be prescribed with certain conditions.

5. Also, abolition of planning commission has created an institutional vacuum with respect to transfers outside finance commissions and therefore, there must be a regulatory body which must regulate such funding. 


\section{References}

- Arghya Sengupta, et.al, Examination of the Legal Basis for Conditional Transfers to States and Issues Relating to Performance-Based Incentives for States: Report to the Fifteenth Finance Commission, Vidhi Centre for Legal Policy, 2018.

- Avani Kapur, Towards Cooperative Social Policy Financing in India, Centre for Policy Research, 2019

- B. P. R. Vithal, Role of Articles 275 and 282 in Federal Fiscal Transfers, Economic and Political Weekly, Vol. 32, No. 28 (Jul. 12-18, 1997), pp. 1689-1691

- Bhim Singh v. Union of India, (2010) 5 SCC 538)

- Bibek Debroy, A review of centrally sponsored schemes, The new Indian Express Newspaper, 2021.

- Constituent Assembly of India Debates (proceedings)

- Dr. Ambedkar, B.R, States and Minorities, 1945.

- Kumar Anupama, Centrally Sponsored Schemes and Centre-state Relations: A Comment, Dvara Research, 2020

- Pranay Kotasthane, The Shifting Political Economy of Centrally Sponsored Schemes, The Wire, 2016

- Rajeshwari Deshpande, Louise Tillin, \& K.K. Kailash. States as laboratories: The politics of social welfare policies in India. (2017) 16(1) 85-105

- Rathin Roy, Changing Fiscal Dynamics, Seminar Magazine 717 (2019)

- Reddy, Y. V., and G. R. Reddy. 2019. Indian Fiscal Federalism. Oxford, UK: Oxford University Press

- Report of the Sub-Group of Chief Ministers on Rationalisation of Centrally Sponsored Schemes, 2016.

- Response to Questionnaire from the Commission on Centre -State Relations, Government of India

- Speech of Shri N.K. Singh, Chairman, XVFC at the launch of the book 'Indian Fiscal Federalism, Press Information Bureau, 2019. Available at:

- The Constitution of India, 1950

- The Government of India Act 1935 